\begin{tabular}{|c|c|c|c|c|c|c|}
\hline \multirow{4}{*}{ Impact Factor: } & ISRA (India) & $=3.117$ & SIS (USA) & $=0.912$ & ICV (Poland) & $=6.630$ \\
\hline & ISI (Dubai, UAE & $=\mathbf{0 . 8 2 9}$ & РИНЦ (Russia & $=0.156$ & PIF (India) & $=1.940$ \\
\hline & GIF (Australia) & $=0.564$ & ESJI (KZ) & $=8.716$ & IBI (India) & $=4.260$ \\
\hline & JIF & $=1.500$ & SJIF (Morocco & $=5.667$ & OAJI (USA) & $=0.350$ \\
\hline
\end{tabular}

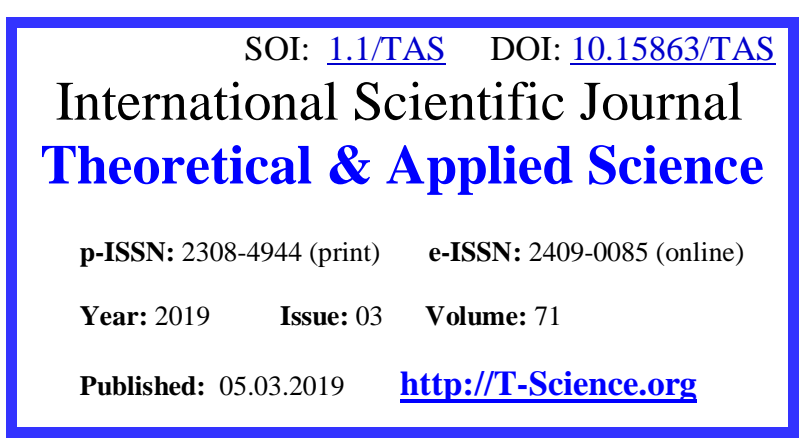

SECTION 4. Computer science, computer engineering and automation.
QR - Issue

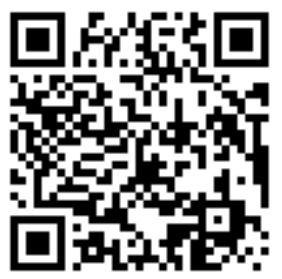

QR - Article

Doniyorbek Kambaraliyevich Ahmadaliev $\mathrm{PhD}$ candidate at Northeast Normal University, China

\section{Asilbek Abduvaliyevich Medatov Department of Information Technologies, Andijan state university, Uzbekistan \\ Mansurbek Mirkomilovich Jo'rayev Software engineering, Tashkent university of information technologies (Fergana branch) \\ Nodirbek Toxirjonovich O'rinov Department of Information Technologies, Andijan state university, Uzbekistan}

\title{
ADAPTIVE EDUCATIONAL HYPERMEDIA SYSTEMS: AN OVERVIEW OF CURRENT TREND OF ADAPTIVE CONTENT REPRESENTATION AND SEQUENCING
}

Abstract: Educational hypermedia systems are being increasingly used in both formal and informal educational settings. Diversely increasing hypermedia contents expect personalization of the content for user traits. In this paper, we have overviewed the current trends of research which focused on content representation and content sequencing.

Key words: adaptive learning, learning style, cognitive style, user models, intelligent tutoring systems.

Language: English

Citation: Ahmadaliev, D. K., Medatov, A. A., Jo'rayev, M. M., \& O'rinov, N. T. (2019). Adaptive educational hypermedia systems: an overview of current trend of adaptive content representation and sequencing. ISJ Theoretical \& Applied Science, 03 (71), 58-61.

\section{Soi: http://s-o-i.org/1.1/TAS-03-71-7 Doi: crossef https://dx.doi.org/10.15863/TAS.2019.03.71.7}

\section{Introduction}

Adapting the context according to user traits in hypermedia started emerging in pioneer period of hypermedia technology. As the content on the web increases and topology of the hyperspace got complexes, user navigation and content representation problems start emerging. Spectrum of user navigation problems are wide and adaptive user navigation in the web is in its infant. Additionally, both - personalized content representation and adaptive content sequencing - are gaining researchers' resent attention. User model is a central aspect of an adaptive system. In order to provide an adaptive user experience, the system should take the following aspects in to consideration:

What to present now: adaptive representation (referring to the extend to what information the system should present and how to organize and display)

What is next: adaptive learning content workflow (Adaptive user navigation)

Possible approaches are: content/link ordering/sorting, progress-based adaptation. It is worth to mention that, dynamically link ordering is not efficient, since overtime user may get different menu/list order. It may be different for different user (every user may have content order according to their preference).

This paper is an overview from the perspective of adaptive content presentation and sequencing in the context of adaptive educational hypermedia. The next section is designed to define the topic and in addition indicates the objectives of the work. Next, learning traits which overviews the concepts and 


\begin{tabular}{|c|c|c|c|c|c|c|}
\hline \multirow{4}{*}{ Impact Factor: } & ISRA (India) & $=3.117$ & SIS (USA) & $=0.912$ & ICV (Poland) & $=6.630$ \\
\hline & ISI (Dubai, UAE & $=0.829$ & РИНЦ (Russia & $=0.156$ & PIF (India) & $=1.940$ \\
\hline & GIF (Australia) & $=0.564$ & ESJI (KZ) & $=8.716$ & IBI (India) & $=4.260$ \\
\hline & JIF & $=1.500$ & SJIF (Morocco & $=5.667$ & OAJI (USA) & $=0.350$ \\
\hline
\end{tabular}

identifies emerging new factors. Then, a close lookup for content representation and content sequencing is presented. And, influential initiatives are reviewed to capture state-of-the-art contributions.

\section{Define AEHS}

Importance of adapting the context for individual preference in hyperspace started emerging in the evolving stage of hypermedia technologies [1]. Adaptation effects may be different based on different kind of adaptive systems [2]. Adequateness of Web-based learning environments should not be any more accounted by its complexity and equipped with a rich of tools/utilities. Resent literature on evaluation of learning on the Web or any other elearning environment require considering to individual learners' preferences and progress. In this sense, there is a requirement of providing a personalized content representation and personalized user navigation which lead the user through a correct/appropriate learning path.

Despite of advantages of learning through the web, it has been very early identified that the user is in peril of getting lost in hyperspace. In other words, student's browsing-behavior may lessen his awareness, increasing numbers of wrong visits to the same page by non-sequential navigation [3]. pathway/sequencing.

User models provide valuable information for adaptive system and this information will be used usually for adaptive content presentation and adaptive learner navigation.

\section{Learner traits}

Literature in cognitive science states that, learners have different perceptions toward the form of the Web content. It is shaped by their nature of preferences. It is referred to learning styles such as the field independent learners prefer nonlinear structured hypermedia, whereas field dependent learners heavily rely on structured presentation of learning material / prefer linear format representation [4]. If we take the web browsing as relatively complex practice and take the above mentioned perspective Chen suggested that educational hypermedia system should be designed by considering different user's cognitive styles.

Many theoretical approaches in learning traits and their practice in hypermedia have been suggested. Among them, in AEHS, learning style classifications, including [5] and [6] models are mostly attracted ones by resent literature. The ones mentioned before and many others are evolved and emerged by motivating with Witkin's be-polar dimensional cognitive styles [7]. Witkin's Fielddependence/independence well indicates how a learner perceives information based on the field arrangement [8].

\section{Cognitive styles}

Field-dependent/independent students prefer and navigate the hypermedia systems differently, where users with Field-dependent behavior feel more needed for guided navigation, while Fieldindependent users prefer freedom of navigation with hypermedia.

In the end, learning tools that allow direct and fast approaches by applying query searching or index may support field-independent users. While, good instructional design, well user navigation supplement and rich user interface should be considered for Field-Dependent learners.

Chen could have identified the importance of support of hypertext navigation types for field in/dependent learners well. But his attention was not drawn toward natural/balanced cognitive style learners. Also, Chen's review has showed Fieldindependent learners risen and it clearly claims that with this cognitive style, learners are more mature on complex hypermedia systems.

\section{Learning styles}

Learning style - there are many competitive definitions for learning style, but the definition given in [9] is widely used, which states that: a learning style is the composite of characteristic cognitive, effective, and psychological factors that serve as relatively stable indicators of how a learner perceives, interacts with, and responds to the learning environment. In the field of learning style, various models exist and they have different theoretical orientations towards different disciplines. Furthermore, as [7] reports that there are more than 70 worthy learning style models available. Among these models, Felder-Silverman Learning Style Model [6] is the most frequently being used in engineering education related studies

Contemporary e-learning environments come with a ready package of several tools and features and require less extra effort on establishing them. For instance, social interaction features and chat forms, assessment and so on.

What was said then and have been made so far on AEHS

(Brusilovsky, 2001) introduced two user characteristics - user's interests and individual traits to user's goals, knowledge, background, hyperspace experience, and preferences. Since these two additional items were not new which to for using in user modeling, but they were new for adaptive hypermedia. Adaptive link generation was suggested to include in to adaptive hypermedia taxonomy to improve adaptive navigation (annotation and sorting) (Brusilovsky, 2001).

\section{Adaptive content presentation}

Most research efforts on establishing an adaptive learning environments usually emphasis to find an appropriate way of representing the learning content which addresses individual user's preferences. In general, context proper expression is especially critical to supporting students on constructing the knowledge in their mind [4]. 


\begin{tabular}{|c|c|c|c|c|c|c|}
\hline \multirow{4}{*}{ Impact Factor: } & ISRA (India) & $=3.117$ & SIS (USA) & $=0.912$ & ICV (Poland) & $=6.630$ \\
\hline & ISI (Dubai, UAE & $=0.829$ & РИНЦ (Russia & $=0.156$ & PIF (India) & $=1.940$ \\
\hline & GIF (Australia) & $=0.564$ & ESJI (KZ) & $=8.716$ & IBI (India) & $=4.260$ \\
\hline & JIF & $=1.500$ & SJIF (Morocco & $=5.667$ & OAJI (USA) & $=0.350$ \\
\hline
\end{tabular}

In order to avoid disorientation link ordering or content hightailing can be possible approach. In massive hyperspace, managing to properly use of font settings is time-consuming and error prone. But it's possible use content categorization and present by utilizing nearest neighbor techniques [10].

\section{Adaptive content sequencing}

In the area of remedial learning path finder systems different approaches have been applied to establish an appropriate learning pathways. These systems' common aim is to ensure users to have an appropriate content sequence and free of disruptions. Cognitive studies showed that different learners have been shown differentially to prefer linear and nonlinear pathways through hypermedia systems [11].

\section{Link ordering}

Web pages are equipped with set of links and they may be huge in number. As this number increases their proper order is required for kipping the usability. Link ordering in adaptive content sequencing (sometimes referred as user navigation) is frequently seen as an approach to represent the content according to the factors of user valuable. Many systems - search engines (Google, Bing, Baidu, etc.), e-commerce services (Amazon, Alibaba, e-Buy, etc.) - potentially applies link ordering techniques. Ordering objectives may be based on importance or popularity or usefulness or in general based on the preferences of an individual user. Adaptive link ordering was used first in 1990, but mostly mentioned example is HYPERFLEX [12]. By reducing navigation time and number of steps in order to locate the target content which the user looking for, link ordering is significantly important for complementing the factors such as "lost in the Web".

\section{Tools}

Brusilovsky proposed an open social student modeling (OSSM) which is a tool to facilitate a social interaction/aware. His tool can also be seen as a holistic content navigation, whereas the tool provides a progress visualization [13].

De Bra highlighted the great potential of Ajax (in other words Web 2.0) in adaptation of content presentation and identification of user navigation behavior dynamically. Since then, the extension of AHA! [14] and many other tools [15]. Such tools which provide the content in an intelligent way sometimes referred as intelligent tutoring systems (ITS)

\section{Intelligent Tutoring systems}

ITS definitions can be found at [16]. An adaptive hypermedia environment can be categorized in ITS as it uses artificial intelligent approaches and evaluates the system and user performance periodically by using Machine learning techniques. As we mentioned earlier, an intelligent tutor uses the values of user and system behavior to maintain the user model and provide adaptation according to the predefined instructions.

Adaptation process is based on uncertainty and ITSs in this area apply recently Bayesian probabilistic approaches. Bayesian network is graphical acyclic model to encode probabilistic relationships of what we are interested to predict. Bayesian network has ideal structure that can represent prior knowledge with in causal form and observed data.

\section{Conclusions}

An overview of the current trends of adaptive content presentation and sequencing in the context of adaptive educational hypermedia is made in this paper. Since the sufficient approaches are available for application in educational hypermedia, we cannot see the wide and practical examples of adaptive hypermedia systems which apply with supporting multi-dimensional user preferences. Observation of user navigation behavioral data usually comes from different activities. Nevertheless, adaptive systems usually presented are not paying more attention rich and motivational user activities.

In the future, we hope to see adaptive hypermedia systems with utilized aforementioned aspects of user.

References:

1. Brusilovsky, P. (1996). Methods and techniques of adaptive hypermedia. User Modeling and User-Adapted Interaction, vol. 6, no. 2-3, 87129.
2. Brusilovsky, P. (2013). Adaptive Hypermedia for Education and Training. (pp. 46-68).

3. Conklin, J. (1987). Hypertext: an introduction and survey. IEEE Computer, vol. IEEE Computer, no. 20, 17-45. 


\begin{tabular}{|c|c|c|c|c|c|c|}
\hline \multirow{4}{*}{ Impact Factor: } & ISRA (India) & $=3.117$ & SIS (USA) & $=0.912$ & ICV (Poland) & $=6.630$ \\
\hline & ISI (Dubai, UAE & $=0.829$ & РИНЦ (Russia) & $=0.156$ & PIF (India) & $=1.940$ \\
\hline & GIF (Australia) & $=0.564$ & ESJI $(\mathrm{KZ})$ & $=8.716$ & IBI (India) & $=4.260$ \\
\hline & JIF & $=1.500$ & SJIF (Morocco) & $=5.667$ & OAJI (USA) & $=0.350$ \\
\hline
\end{tabular}

4. Chen, S. Y., \& Macredie, R. D. (2002). Cognitive Styles and Hypermedia Navigation: Development of a Learning Model. Journal of the american society for information science and technology, vol. 53, no. 1, 3-15.

5. Kolb, D. A. (1984). Experiential Learning: Experience as the Source of Learning and Development (Prentice-Hall).

6. Felder, R. M., \& Silverman, L. K. (1988). Learning and teaching styles in engineering education. Engineering education, vol. 78, no. 7, 674-681.

7. Coffield, F., Moseley, D., Hall, E., \& Ecclestone, K. (2004). Learning styles and pedagogy in post-16 learning: A systematic and critical review, ed: Learning and Skills Research Centre London.

8. Weller, H. G., Repman, J., \& Rooze, G. E. (1994). The relationship of learning, behavior, and cognitive style in hypermedia-based instruction: implications for design of HBI. Computers in the Schools, vol. 10, no. 3-4, 401-418.

9. Keefe, J. W. (1979). Learning style: An overview. Student learning styles: Diagnosing and prescribing programs, vol. 1, 1-17.

10. Kahraman, H. T., Sagiroglu, S., \& Colak, I. (2013). The development of intuitive knowledge classifier and the modeling of domain dependent data. (pp.283-295). Elsevier Science Publishers B. V..

11. Sherry, R. D. M., \& Chen, Y. (2002). Cognitive Styles and Hypermedia Navigation:
Development of a Learning Model. Journal of the american society for information science and technology, vol. 53, no. 1, 3-15.

12. Kaplan, C., Fenwick, J., \& Chen, J. (1993). Adaptive hypertext navigation based on user goals and context. User modeling and useradapted interaction, vol. 3, no. 3, 193-220.

13. Brusilovsky, P., Somyürek, S., Guerra, J., Hosseini, R., Zadorozhny, V., \& Durlach, P. J. (2016). Open Social Student Modeling for Personalized Learning," IEEE Transactions on Emerging Topics in Computing, vol. 4, no. 3, 450-461.

14. De Bra, P., Smits, D., \& Stash, N. (2006). The design of AHA!(Introduction)," in Proceedings of the 17th ACM Conference on Hypertext and Hypermedia (HT'06, Odense, Denmark, August 22-25, 2006), ACM Press.

15. Ahmadaliev, D. Q., Xiaohui, C., \& Abduvohidov, M. (2018). A Web-based Instrument to Initialize Learning Style: An Interactive Questionnaire Instrument. International Journal of Emerging Technologies in Learning (iJET), vol. 13, no. 12, 238-246.

16. Vandewaetere, M., Desmet, P., \& Clarebout, G. (2011). Review: The contribution of learner characteristics in the development of computer-based adaptive learning environments. Elsevier Science Publishers B. V., 118-130. 